\title{
Patch Test Results in Patients with Suspected Contact Dermatitis at a Tertiary Care Hospital in a Semiurban Area in Rajasthan: A Cross-sectional Study
}

\author{
${ }^{1}$ Pallavi Goyal, ${ }^{2}$ Manisha Nijhawan, ${ }^{3}$ Savita Agrawal, ${ }^{4}$ Sinni Jain, ${ }^{5}$ Rakesh Jangra
}

\begin{abstract}
Contact dermatitis is an inflammatory condition of the skin after exposure to any exogenous substance. It can be classified as irritant contact dermatitis (ICD) and allergic contact dermatitis (ACD). A cross sectional study was conducted in Mahatma Gandhi Hospital over a period of 3-month duration from March-May 2016 and total 68 patients with suspected contact dermatitis were subjected to patch test. Most common allergen found to be positive in both males and females was parthenium followed by fragrance mix.
\end{abstract}

Keywords: Contact dermatitis, Cross-sectional, Fragrance mix, Parthenium, Patch test.

How to cite this article: Goyal P, Nijhawan M, Agrawal S, Jain $S$, Jangra R. Patch Test Results in Patients with Suspected Contact Dermatitis at a Tertiary Care Hospital in a Semiurban Area in Rajasthan: A Cross-sectional Study. J Mahatma Gandhi Univ Med Sci Tech 2016;1(1):1-4.

\section{Source of support: None}

Conflict of interest: Nil

\section{INTRODUCTION}

Contact dermatitis is an inflammatory condition of the skin after exposure to any foreign/exogenous substance and it can be classified as irritant and allergic contact dermatitis (ICD and ACD). It accounts for 4 to $7 \%$ of all patients attending dermatology outpatient department which is of major concern. ${ }^{1}$ Prevalence and etiology of contact dermatitis is affected by various determinants including geographic area, socioeconomic status, and occupation. Patch testing is the gold standard method for the diagnosis of ACD. Study was performed to observe the prevalence of patch test positivity in patients with suspected contact dermatitis patients and try to correlate occupation with patch test reactions to various allergens in Indian standard series.

\footnotetext{
${ }^{1,5}$ Resident (3rd Year), ${ }^{2}$ Professor and Head, ${ }^{3}$ Assistant Professor, ${ }^{4}$ Resident

${ }^{1-5}$ Department of Dermatology, Venereology and Leprosy Mahatma Gandhi Hospital, Jaipur, Rajasthan, India

Corresponding Author: Pallavi Goyal, PG Hostel, 4A Mahatma Gandhi Hospital, RIICO Industrial Area, Sitapura Jaipur, Rajasthan, India, Phone: +91-9813331635, e-mail: drpallavigoel@gmail.com
}

\section{MATERIALS AND METHODS}

This cross-sectional study was done in Mahatma Gandhi Hospital over a period of 3 months duration from MarchMay 2016. A total 68 patients with suspected contact dermatitis were included in the study. Details regarding age, sex, clinical diagnosis, duration, and occupation were noted. Presenting clinical features included papules, papulovesicles, edema, erythema, crusting, scaling, and lichenification.

All the patients were patch tested using the Indian Standard Series consisting of twenty common contact allergens which is approved by Contact and Occupational Dermatoses Forum of India (CODFI). Patients were asked to avoid oral antihistaminics, oral steroids or other immunosuppressive agents and application of topical steroids at the site of patch testing 2 weeks before testing. Patients were asked to come after 2 days for interpretation of result. Grading of patch test results was done by using International Contact Dermatitis Research Group (ICDRG) guidelines as shown in Figure 1.

Indian Standard Series of contact allergens includes the following allergens:

1. Vaseline $100 \%$

2. Wool alcohol $30 \%$

3. Balsam of Peru $10 \%$

4. Formaldehyde $2 \%$

5. Mercaptobenzothiazole $1 \%$

6. Bichromate $0.1 \%$

7. Nickel sulfate $5 \%$

8. Cobalt sulfate $5 \%$

9. Colophony $10 \%$

10. Epoxy resin $1 \%$

11. Paraben mix $9 \%$

12. Paraphenylenediamine

13. Parthenium $15 \%$

14. Neomycin sulfate $20 \%$

15. Benzocaine $5 \%$

16. Chlorocresol $1 \%$

17. Fragrance mix $8 \%$

18. Thiuram mix $1 \%$

19. Nitrofurazone $1 \%$

20. Black rubber mix $0.6 \%$ 


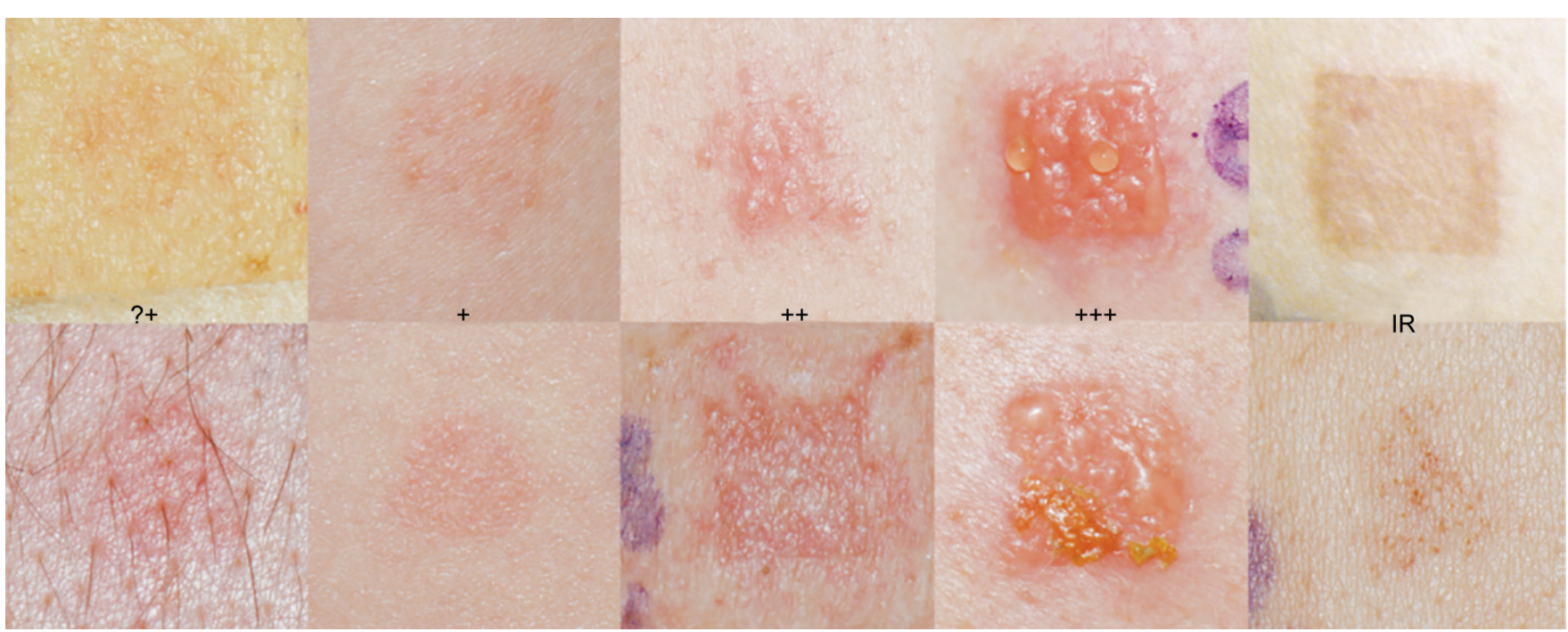

Fig. 1: Notation of positive patch test results according to ICDRG

Table 1: Patch test results

\begin{tabular}{|c|c|c|c|c|}
\hline Occupational groups & Number of patients & $\begin{array}{l}\text { Number of patients } \\
\text { positive for patch test }\end{array}$ & Allergen & $\begin{array}{l}\text { No. of positive } \\
\text { reactions }\end{array}$ \\
\hline Housewives & 22 & 9 & $\begin{array}{l}\text { Nickel sulfate } \\
\text { Paraphenylenediamine } \\
\text { Fragrance mix } \\
\text { Colophony } \\
\text { Epoxy resin } \\
\text { Balsam of peru } \\
\text { Mercaptobenzothiazole } \\
\text { Chlorocresol } \\
\text { Black rubber mix }\end{array}$ & $\begin{array}{l}3 \\
3 \\
3 \\
2 \\
2 \\
1 \\
1 \\
1 \\
1\end{array}$ \\
\hline Farmers & 21 & 16 & $\begin{array}{l}\text { Parthenium } \\
\text { Fragrance mix } \\
\text { Mercaptobenzothiazole } \\
\text { Colophony } \\
\text { Wool alcohol } \\
\text { Neomycin sulfate } \\
\text { Thiuram mix } \\
\text { Black rubber mix }\end{array}$ & $\begin{array}{l}13 \\
6 \\
3 \\
2 \\
1 \\
1 \\
1 \\
1\end{array}$ \\
\hline Teachers & 3 & 3 & $\begin{array}{l}\text { Parthenium } \\
\text { Mercaptobenzothiazole } \\
\text { Neomycin sulfate } \\
\text { Fragrance mix }\end{array}$ & $\begin{array}{l}2 \\
1 \\
1 \\
1\end{array}$ \\
\hline Cement workers & 4 & 4 & $\begin{array}{l}\text { Bichromate } \\
\text { Epoxy resin }\end{array}$ & $\begin{array}{l}4 \\
1\end{array}$ \\
\hline Students & 7 & 2 & $\begin{array}{l}\text { Bichromate } \\
\text { Paraphenylenediamine }\end{array}$ & $\begin{array}{l}2 \\
1\end{array}$ \\
\hline Shopkeepers & 3 & 1 & Thiuram mix & 1 \\
\hline Mechanic & 1 & 1 & Nickel sulfate & 1 \\
\hline Office workers & 2 & 2 & $\begin{array}{l}\text { Fragrance mix } \\
\text { Bichromate }\end{array}$ & $\begin{array}{l}2 \\
1\end{array}$ \\
\hline Businessmen & 2 & 2 & $\begin{array}{l}\text { Neomycin sulfate } \\
\text { Chlorocresol } \\
\text { Fragrance mix } \\
\text { Black rubber mix }\end{array}$ & $\begin{array}{l}1 \\
1 \\
1 \\
1\end{array}$ \\
\hline Nursing staff & 2 & 2 & $\begin{array}{l}\text { Formaldehyde } \\
\text { Bichromate } \\
\text { Colophony }\end{array}$ & $\begin{array}{l}2 \\
1 \\
1\end{array}$ \\
\hline TV anchor & 1 & 1 & Wool alcohol & 1 \\
\hline Total & 68 & 43 & & 72 \\
\hline
\end{tabular}




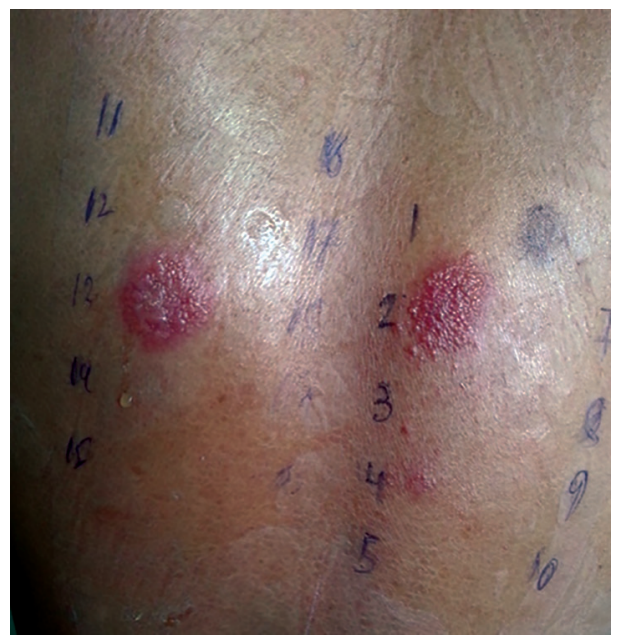

Fig. 2: Positive reaction with wool alcohol (2) and parthenium (13)

The allergens were obtained from Systopic Pharmaceuticals (P) Ltd., New Delhi.

The results are tabulated in Table 1.

\section{RESULTS}

Out of 68 patients, 38 were males $(55.9 \%)$ and 30 were females (44.1\%) with age ranging from 10 to 65 years. Patch test was positive in 43 patients $(63.2 \%)$. Most common allergen found to be positive in was parthenium followed by fragrance mix. Allergens, like vaseline, cobalt sulfate, paraben mix, benzocaine and nitrofurazone, did not come positive at all. In males, most common positive allergen was parthenium. In females, no specific allergen was found to be most common. Infact, three allergens, e.g., parthenium, fragrance mix and mercaptobenzothiazole, were found to be positive in four patients each.

In our study, most common group of patients were housewives followed by farmers. Among housewives, most common allergens were nickel sulfate, paraphenylenediamine and fragrance mix. Among farmers, most common allergen was parthenium followed by fragrance mix. Total number of positive reactions were 72 out of which 28 were seen in farmer group as can be seen in Figures 2 and 3.

\section{DISCUSSION}

Patch testing is a useful, evidence based method for diagnosis of allergic contact dermatitis. Main component for management of allergic contact dermatitis is prevention from contact with causative allergens. ${ }^{2,3}$ Occupational allergic contact dermatitis plays an important role among patients with contact dermatitis. A total of 0.7 to $1.4 \%$ of the general population and $4.5 \%$ of occupationally exposed groups is affected by compositae dermatitis. ${ }^{4}$ Parthenium hysterophorus, commonly known as "congress grass" is

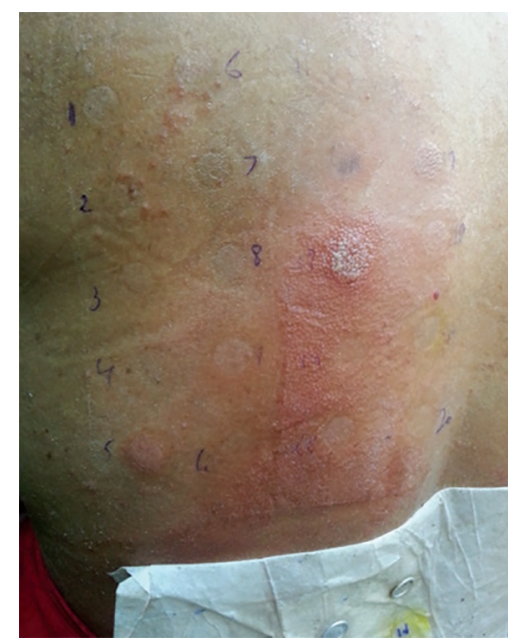

Fig. 3: Positive reaction with mercaptobenzothiazole (5) and parthenium (13)

a member of Compositae family, introduced in India in 1950s. ${ }^{5,6}$ It is the most common cause of plant dermatitis in India. ${ }^{7}$ Main allergen causing contact dermatitis are sesquiterpene lactones (SQLs). ${ }^{8}$ Fragrance mix is found in perfumes, deodorants, insect attractants, toothpaste and soft drinks. Mercaptobenzothiazole and thiuram mix are found in rubber, fungicides, disinfectant soaps and cutting oils. In Bajaj et al's series, 14 out of 102 cases were positive to mercaptobenzene. ${ }^{9}$ Bichromate is found in leather, cement, rubber, and glass. In India, chrome free leather is not much in use due to its non-availability and high cost. Chromates are most common allergens responsible for shoe dermatitis in India. The commonest allergen detected in a study done at Kerala was potassium dichromate $(24 / 47 ; 51 \%)$ followed by fragrance mix (12/47; $25.5 \%)$ and parthenium $(4 / 47 ; 8.5 \%) .{ }^{10}$ In a study conducted at West Bengal, the four most common allergens were paraben $(n=30,43 \%)$, potassium dichromate $(n=19,27 \%)$, fragrance mix $(n=18,26 \%)$ and cobalt chloride $(n=16$, $23 \%)^{11}$

\section{CONCLUSION}

Patch testing aids in diagnosis of contact dermatitis which is a rising problem nowadays. Proper and early diagnosis helps in taking necessary preventive measures and stopping or minimizing recurrence and can also act as a guide for the patients to choose the right occupation. Patient should be counselled how to avoid contact with implicated allergens and this forms an integral part of the care plan for the patient.

\section{REFERENCES}

1. Mendenhall RG, Ramsay DL, Girard RA. A study of the practice of dermatology in the United States. Arch Dermatol 1978;114(10):1456-1462. 
2. Bajaj AK, Saraswat A, Mukhija G, Rastogi S, Yadav S. Patch testing experience with 1000 patients. Indian J Dermatol Venereol Leprol 2007;73(5):313-318.

3. Vender RB. The utility of patch testing children with atopic dermatitis. Skin Therapy Lett 2002;7(6):4-6.

4. Sharma VK, Gomathy S, Bhat R. Evolution of clinical pattern of parthenium dermatitis: a study of 74 cases. Contact Dermatitis 2005;53(2):84-88.

5. Guin JD. Sesquiterpene-lactone dermatitis. Immunol Allergy Clin North Am 1989;9:447-461.

6. Mitchell JC, Calnan CD. Scourge of India. Parthenium dermatitis. Int J Dermatol 1978;17(4):303-304.

7. Sharma VK. Patch testing with the European standard series and compositae extracts in patients with airborne contact dermatitis. Contact Dermatitis 2001;44(1):49-50.
8. Lonkar A, Nagasampagi BA, Narayanan CR, Landge AB, Sawaikar DD. An antigen from Parthenium hysterophorus Linn. Contact Dermatitis 1976;2(3):151-154.

9. Bajaj AK, Gupta SC, Chatterjee AK, Singh KG. Shoe dermatitis in India: further observations. Contact Dermatitis 1991;24:(2) 149-151.

10. Prathap P, Kumar KA, Asokan N, Betsy, Binesh VG. Occupational Allergic Contact Dermatitis: a clinical study in a tertiary care centre in central Kerala. Indian J Dermatol 2012:57(5):409-410.

11. Sarma N, Ghosh S. Clinico-allergological pattern of allergic contact dermatitis among 70 Indian children. Indian J Dermatol Venereol Leprol 2010;76(1):38-44. 